\title{
KARAKTERISTIK PERUSAHAAN, KELENGKAPAN PENGUNGKAPAN LAPORAN KEUANGAN DAN KEMUNGKINAN KECURANGAN PELAPORAN KEUANGAN
}

\author{
Husaini $^{1}$, Salma Yuniza ${ }^{2}$ \\ ${ }^{1,2}$ Universitas Bengkulu \\ husaini@unib.ac.id
}

\begin{abstract}
This research aims to obtain empirical evidence regarding the effect of the characteristics of the company's financial disclosure statements of completeness and consequently to the financial statement fraud. Characteristics of companies in this study consists of company size, leverage, liquidity, the company's corporate status and age.The population in this research is the manufacturing companies listed on the Indonesia stock exchange over the years 2011-2013. Purposive sampling method based on retrieved 98 companies listed on the Indonesia stock exchange as research samples. Research on regression model using two. Using multiple linear regression, the study found the size of the company and the company's status affect the completeness of the disclosure of the financial statements. Leverage, liquidity and the age of the company does not affect the completeness of the disclosure of the financial statements. Then, the sample is categorized into 2 categories by using the Beneish model M-Score that the company that did the possibility of fraudulent financial reporting and company didn't do the possibility of fraudulent financial reporting. Using the method of logistic regression, this research found that the completeness of the pengungakap financial statements have no effect against the possibility of fraud in financial reporting.
\end{abstract}

Keywords: Disclosure Of Financial Statment Completeness, Financial Statement Fraud, Characteristics Of The Company's .

\section{PENDAHULUAN}

Laporan keuangan merupakan media komunikasi yang digunakan untuk menghubungkan pihakpihak yang berkepentingan terhadap perusahaan. Tujuan umum laporan keuangan adalah menyediakan informasi keuangan yang bermanfaat untuk pengambilan keputusan. Bagi pihak diluar manajemen suatu perusahaan, laporan keuangan merupakan informasi yang memungkinkan mereka mengetahui kondisi perusahaan tersebut. Seberapa besar informasi yang dapat diperoleh sangat tergantung pada tingkat pengungkapan (disclosure) dari laporan keuangan perusahaan yang bersangkutan.Devi dan Suardana (2014) menyatakan suatu laporan keuangan dapat bermanfaat bagi sejumlah besar pengguna apabila informasi yang disajikan dalam laporan keuangan tersebut dapat dipahami, relevan, handal dan dapat diperbandingkan. Informasi yang diperoleh dari suatu laporan keuangan tergantung juga pada tingkat kelengkapan pengungkapan (disclosure) laporan keuangan yang bersangkutan. Menurut Naim dan Rakhman dalam Kartika (2009) menyatakan terdapat dua jenis pengungkapan (disclosure) yaitu pengungkapan wajib (mandatory disclosure) merupakan pengungkapan yang diwajibkan oleh peraturan pemerintah dan pengungkapan sukarela (voluntary disclosure) merupakan pengungkapan yang tidak diwajibkan peraturan.

Di Indonesia, praktik pengungkapan informasi perusahaan publik telah diatur melalui badan regulator pasar modal yaitu Badan Pengawas Pasar Modal dan Lembaga Keuangan (BAPEPAM-LK, Sekarang OJK) dengan keputusan Ketua Bapepam dan LK Nomor: Kep-134/BL/2006 tanggal: 7 Desember 2006 dimana pedoman ini memuat tentang ikhtisar data keuangan penting, laporan dewan komisaris, laporan direksi, profil perusahaan, analisis dan pembahasan manajemen dan tata kelola perusahaan (corporate governance) yang merupakan pedoman penyajian dan pengungkapan laporan keuangan oleh emiten atau perusahaan publik industri manufaktur ditetapkan oleh Bapepeam.Surat edaran Nomor: SE03/BL/2011 Tanggal: 13 Juli 2011 tentang pedoman penyajian dan pengungkapan laporan keuangan oleh emiten atau perusahaan publik industri manufaktur ditetapkan oleh Bapepam dimana pedoman ini memuat informasi tetap berlakunya surat edaran Nomor: SE-02/PM/2002 tentang pedoman penyajian dan pengungkapan 
Laporan keuangan emiten atau perusahaan publik sepanjang tidak bertentangan dengan peraturan Nomor VIII.G.7 lampiran Keputusan Ketua Badan Pengawas Pasar Modal dan Lembaga Keuangan Nomor: Kep-554/BL/2010 tanggal 30 Desember 2010 tentang perubahan keputusan ketua Bapepam Nomor: Kep-06/PM/2000 tentang perubahan peraturan Nomor VIII.G.7 tentang pedoman penyajian laporan keuangan.Meskipun badan regulator telah mengeluarkan peraturan tentang pengungkapan laporan keuangan, ternyata peraturan tersebut belum sepenuhnya dipatuhi oleh perusahaan yang listing di BEI. Hal ini sesuai dengan penelitian sebelumnya yang dilakukan oleh Purwandari dan Purwanto (2012) pada perusahaan manufaktur yang go public di BEI bahwa kelengkapan pengungkapan laporan keuangan perusahaan masih sekitar 43,72\%.Adanya persaingan bisnis yang tinggi dalam lingkup yang semakin sulit seperti terjadinya krisis finansial global, telah mempengaruhi pelaku bisnis dalam berbagai aspek. Dalam kondisi krisis finansial yang terjadi disatu sisi pelaku bisnis tetap dituntut untuk tersedianya informasi yang benar-benar akurat dan relevan, sebab publik sebagai customer utama terhadap informasi ini sangat berkepentingan dalam proses pengambilan keputusan. Disisi lain akibat dari krisis finansial ini juga menimbulkan keinginan para pelaku bisnis untuk menutupi informasi yang dapat memperlihatkan kondisi perusahaan yang kurang baik terkait dengan keuangannya.

Di Indonesia, Bapepam-LK menemukan sejumlah perusahaan yang terdeteksi melakukan kecurangan (fraud) (Bapepam-LK, 2002). Kasus kecurangan pelaporan keuangan (fraud) juga terjadi di Indonesia, yang berakibat pada pemberian sanksi oleh BEI. Kasus-kasus itu antara lain PT Kimia Farma Tbk., PT Bakrie and Brothers Tbk., PT Bakrie Sumatra Plantation Tbk., PT Energi Mega Persada Tbk., dan PT Benakat Petrolum Energy Tbk.Banyaknya kasus fraud yang ditangani Bapepam menjadi bukti bahwa terdapat kegagalan audit dalam mendeteksi adanya kecurangan laporan keuangan (Daljono, 2013). Semakin tinggi pengungkapan laporan keuangan kemungkinan kecurangan pelaporan keuangan semakin kecil, hal ini sejalan dengan pernyataan Rezaee (2005) yang menyatakan bahwa kecurangan pelaporan keungan berkaitan dengan penghilangan secara sengaja dari pengungkapan atau penyajian pengukapan yang tidak memadai berkaitan dengan standar, prinsip, praktek akuntansi dan informasi keuangan yang berhubungan. Dengan masih mempertimbangkan kelengkapan pengungkapan laporan keuangan peneliti ingin mengetahui konsekuensi dari kelengkapan pengungkapan laporan keuangan terhadap kemungkinan kecurangan pelaporan keuangan.Berdasarkan latar belakang, penelitian inibertujuan untuk menguji pengaruh karakteristik perusahaan yaitu ukuran perusahaan, leverage, likuiditas, umur perusahaan dan status perusahaan terhadap kelengkapan pengungkapan laporan keuangan dan konsekuensinya terhadap kemungkinan kecurangan pelaporan keuangan.

\section{KAJIAN PUSTAKA}

\section{Ukuran Perusahaan dan Kelengkapan Pengungkapan Laporan Keuangan}

Lang dan Lundholm (1993) dalam Benardi dkk. (2009) menyatakan bahwa tingkat keluasan informasi dalam kebijakan pengungkapan perusahaan akan meningkat seiring dengan meningkatnya ukuran perusahaan, hal ini dikarenakan perusahaan yang berukuran lebih besar cenderung memiliki tuntutan publik (publik demand) akan informasi yang lebih tinggi dibanding dengan perusahaan yang berukuran kecil. Wallace dkk dalam Devi dan Suardana (2014) menyatakan perusahaan yang berukuran besar cenderung lebih banyak mengungkapkan butir-butir laporan keuangan karena mereka memiliki lebih banyak informasi yang dapat diungkapkan.Hasil penelitian yang dilakukan Devi dan Suardana (2014) memperoleh bahwa ukuran perusahaan berpengaruh signifikan terhadap kelengkapan pengungkapan laporan keuangan. Hasil ini juga didukung dengan penelitian yang dilakukan oleh Benardi dkk (2009) ysng memperoleh hasil bahwa ukuran perusahaan berpengaruh signifikan terhadap kelengkapan pengungkapan laporan keuangan.Berdasarkan uraian yang ada maka hipotesis ini dapat dinyatakan bahwa.

H1: Ukuran Perusahaan berpengaruh positif terhadap kelengkapan pengungkapan laporan keuangan.

\section{Leverage dan Kelengkapan Pengungkapan Laporan Keuangan}

Leverage merupakan istilah yang sering digunakan perusahaan untuk mengukur kemampuan perusahaan didalam memenuhi seluruh kewajiban finansialnya apabila perusahaan dilikuidasi. Secara umum leverage dapat dihitung dengan membagi total aset dengan total hutang (Purwandari dan Purwanto, 2012).Struktur permodalan perusahaan biasanya terdiri dari modal internal dan eksternal. Modal yang diperoleh dari pihak eksternal yaitu berupa pinjaman dari kreditor. Penggunaan pinjaman tersebut tentunya menuntut adanya pertanggungjawaban perusahaan baik dalam pemakaian maupun pengembalian pinjaman. Pihak kreditor akan selalu memantau dan memerlukan informasi yang lebih luas mengenai 
keadaan financial debitor untuk meyakinkan kreditur bahwa debitur akan dapat memenuhi kewajibannya pada saat jatuh tempo (Wicaksono, 2011).Hasil dari penelitian Mahmud dan Irianto (2009) membuktikan leverage berpengaruh signifikan terhadap kelengkapan pengungkapan laporan keuangan. Hasil ini juga didukung oleh penelitian Almilia dan Retrinasari (2007) yang memperoleh hasil leverage berpengaruh signifikan terhadap kelengkapan pengungkapan laporan keuangan.Berdasarkan uraian yang ada maka hipotesis ini dapat dinyatakan bahwa.

$\mathrm{H} 2$ : leverage berpengaruh positif terhadap kelengkapan pengungkapan laporan keuangan.

\section{Likuiditas pada Kelengkapan Pengungkapan Laporan Keuangan}

Perusahaan yang likuiditasnya tinggi diharapkan melakukan disclosure secara lebih luas. Alasan yang mendasari adalah perusahaan yang secara finansialnya kuat akan lebih mengungkapkan secara luas. Likuiditas akan memberikan kemampuan perusahaan untuk melakukan kegiatannya (Wicaksono, 2011).Hasil penelitian yang Winarto (2012) membuktikan likuiditas berpengaruh signifikan terhadap kelengkapan pengungkapan laporan keuangan. Hasil ini juga didukung oleh penelitian yang dilakukan oleh Christanty (2004) yang juga memperoleh hasil likuiditas berpengaruh signifikan terhadap kelengkapan pengungkapan laporan keuangan. Berdasarkan uraian yang ada maka hipotesis ini dapat dinyatakan bahwa.

H3: likuiditas berpengaruh positif terhadap kelengkapan pengungkapan laporan keuangan.

\section{Umur Perusahaan dan Kelengkapan Pengungkapan Laporan Keuangan}

Umur perusahaan menunjukkan kemampuan perusahaan dapat bertahan hidup dan menjalankan operasionalnya. Irawan (2006) menyatakan bahwa umur perusahaan diperkirakan memiliki hubungan positif dengan kualitas pengungkapan. Alasan yang mendasari adalah bahwa perusahaan yang berumur lebih tua memiliki pengalaman yang lebih banyak dalam mempublikasikan laporan keuangan. Perusahaan yang memiliki pengalaman lebih banyak akan lebih mengetahui kebutuhan konsituennya akan informasi tentang perusahaan.Hasil penelitian yang dilakukan Winarto (2012) membuktikan umur perusahaan berpengaruh signifikan terhadap kelengkapan pengungkapan laporan keuangan. Berdasarkan uraian yang ada maka hipotesis ini dapat dinyatakan bahwa.
H4: Umur perusahaan berpengaruh positif terhadap kelengkapan pengungkapan laporan keuangan.

\section{Status Perusahaan pada Kelengkapan Pengungkapan Laporan Keuangan}

Latar belakang masuknya variabel status perusahaan didorong oleh suatu alasan sederhana yaitu bahwa perusahaan dengan status yang berbeda akan memililki stakeholder yang berbeda, sehingga tingkat kelengkapan pengungkapan yang harus dilakukan berbeda. Status perusahaan menunjukkan tingkat kepemilikan saham dalam suatu perusahaan. Menurut Mahmud dan Irianto (2009) status perusahaan terbagi dua, yaitu: Perusahaan berstatus asing dan perusahaan berstatus domestik.Hasil penelitian yang dilakukan Irawan (2006) membuktikan status perusahaan berpengaruh signifikan terhadap kelengkapan pengungkapan laporan keuangan. Berdasarkan uraian yang ada maka hipotesis ini dapat dinyatakan bahwa.

H5: Status perusahaan berpengaruh positif terhadap kelengkapan pengungkapan laporan keuangan.

\section{Kelengkapan Pengungkapan Laporan Keuangan dan Kemungkinan Kecurangan Pelaporan Keuangan}

Kecurangan adalah tindak kesengajaan untuk menghasilkan salah saji material dalam laporan keuangan yang merupakan subyek audit. Kecurangan merupakan suatu perbuatan tidak wajar yang disengaja, yang dilakukan oleh seseorang dengan segala cara untuk mendapatkan keuntungan dari orang lain dengan cara yang salah atau pemaksaan pembenaran yang dilakukan dengan penuh siasat, licik dan tersembunyi yang mengakibatkan orang lain tertipu, yang dilakukan oleh orang dalam maupun orang luar suatu organisasi. Fraud juga merupakan suatu tindakan pencurian, yang dilakukan dengan penuh kerahasiaan, dengan menyalahgunakan jabatan untuk mengalihkan aktiva-aktiva atau sumber daya yang dicuri ke dalam aktiva-aktiva atau sumber daya pribadi (Husaini, 2009; 134).Latar belakang adanya variabel kemungkinan kecurangan pelaporan keuangan ini adalah dengan semakin baik informasi yang diperoleh terkait dengan kelengkapan pengungkapan laporan keuangan tentu akan memberi dampak semakin kecil juga terjadinya kemungkinan kecurangan pelaporan keuangan. Hal ini sejalan dengan pernyataan Rezaee (2005) yang menyatakan bahwa kecurangan pelaporan keungan berkaitan dengan penghilangan secara sengaja dari pengungkapan atau penyajian pengukapan yang tidak memadai berkaitan dengan standar, prinsip, praktek 
akuntansi dan informasi keuangan yang berhubungan.Berdasarkan hal itu peneliti akan menelitivariabel ini, maka hipotesis penelitian dirumuskan.

H6 : Kelengkapan pengungkapan laporan keuangan berpengaruh negatif terhadap kemungkinan kecurangan pelaporan keuangan.

\section{METODE PENELITIAN}

\section{Populasi dan Sampel}

Populasi dalam penelitian ini adalah seluruh perusahaan manufaktur yang terdaftar di BEI dari tahun 2011 sampai 2013, sedangkat penarikan kampel dilakukan dengan metode purposif sampling, sampel akhir diperoleh 98 perusahaan atau 294 observasi. Adapun sampel penelitian ini disajikan pada Tabel 1 berikut ini.

Tabel 1 Sampel Penelitian

\begin{tabular}{|l|c|}
\hline \multicolumn{1}{|c|}{ Perusahaan Sampel Penelitian } & Jumlah \\
\hline Perusahaan Manufaktur yang terdaftar di BEI tahun 2011 - 2013 & 138 \\
\hline Perusahaan yang menyajikan Laporan Keuangan dalam mata uang Dollar & 34 \\
\hline Perusahaan yang tidak memiliki kelengkapan data & 6 \\
\hline Jumlah Perusahaan yang memenuhi Kriteria dan dijadikan sampel penelitian & 98 \\
\hline
\end{tabular}

Observasi atau pengamatandibagi menjadi 2 kategori yaitu perusahaan yang diindikasikan melakukan fraud dan perusahaan yang diindikasikan tidak melakukan fraud disajikan padaTabel 2 berikut ini.

Tabel 2Sampel Berdasarkan Kategori Perusahaan

\begin{tabular}{|c|c|c|}
\hline Kategori Perushaan & Pengamatan & Presentase (\%) \\
\hline Perusahaan yang dindikasikan melakukan fraud & 162 & $55,1 \%$ \\
\hline Perusahaan yang diindikasikan tidak melakukan fraud & 132 & $42,7 \%$ \\
\hline Jumlah & 294 & $100 \%$ \\
\hline
\end{tabular}

\section{Variabel dan Pengukurannya}

\section{Kelengkapan Pengungkapan Laporan} Keuangan (Disclosure)-Variabel ini diukur denganIndeks Wallace, yaiyu banyak item laporan keuangan yang material diungkap oleh perusahaan dibandingkan jumlah pengungkapan yang mungkin dipenuhi. Adapun item-item yang diungkap dalam penelitian ini mengacu pada Surat Keputusan Bapepam Nomor: SE-03/BL/2011, item-item kelengkapan pengungkapan wajib berjumlah 79item (Kartika, 2009). Variabel berikutnya adalah Kemungkinan Kecurangan Pelaporan Keuangan (Financial Statment Fraud)-Variabel ini diukur denganBeneish M-Score. Perusahaan dengan M-Score tinggi memiliki kemungkinan untuk melakukan fraud. Sebaliknya perusahaan dengan M-Score rendah memiliki kemungkinan yang lebih kecil untuk melakukan fraud. Jika M>2.22, hal ini menunjukkan adanya indikasi perusahaan melakukan manipulasi kecurangan pelaporan keuangan. Variabel kemungkinan kecurangan pelaporan keuangan ini adalah varibel dummy sehingga perusahaan yang melakukan fraud diberi skor 1 sedangkan perusahaan yang tidak melakukan fraud diberi skor 0. Adapun formula
Beneish M-Score adalah sebagai berikut. M-Score $=-4.84+0.920 \mathrm{DSRI}+0.528 \mathrm{GMI}+0.404 \mathrm{AQI}+$ 0.892 SGI + 0.115 DEPI -0.172 SGAI -0.327 LVGI + 4.679 TATA. Ukuran Perusahaan(Size), Ukuran perusahaan dapat diukur dengan Ln total aset. Leverage, diukur dengan Debt to Equity Ratio (DER), yaitu perbandingan total utang dan total ekuitas. Likuiditas, diukur denganaset lancar dibandingkan utang lancar. Umur Perusahaan(Age), tahun sampel dikurangi tahun berdirinya perusahaan.Status Perusahaan, diukur dengen dummy, skor 1 untuk penanaman modal dalam negeri dan skor 0 jika untuk penanaman modal asing.

\subsection{Metode Analisis}

Analisis data pada penelitian ini akan menggunakan dua model regresi, yaitu model regresi linear berganda dan model regresi logistik. Model regresi linear berganda akan digunakan untuk menguji hipotesis 1, 2, 3, 4 dan 5. Sedangkan model regresi logistik akan digunakan untuk menguji hipotesis 6.Adapun modelanalisis regresi yang digunakan dalam penelitian ini adalah, sebagai berikut. 
Volume 8, Nomor 1, Februari, 2020

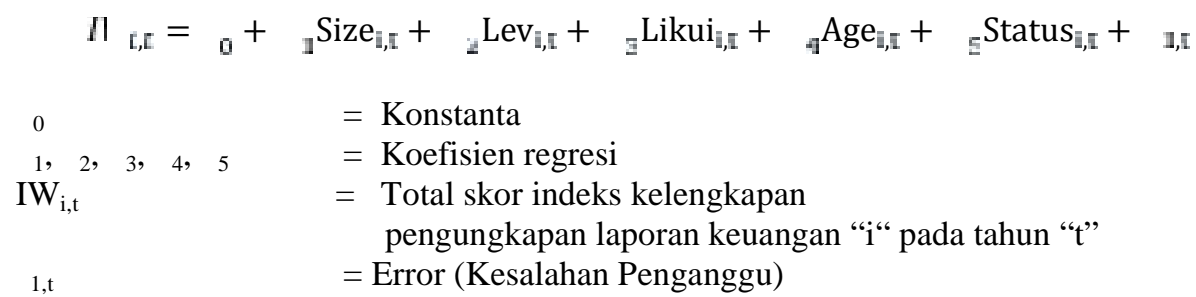

Sedangkan model regresi logistik yang digunakan untuk adalah sebagai berikut.

$\beta_{0}$

$=$ Konstanta

$$
F_{[, \mathrm{L}}=\beta_{0}+\beta_{\mathrm{l}} l_{\mathrm{L}, \mathrm{L}}+\varepsilon_{\mathrm{I}, \mathrm{L}}
$$

$\mathrm{FSF}_{\mathrm{i}, \mathrm{t}}=$ Dinilai dari hasil formulasi Beneish M-Score Model.

Perusahaan yang memiliki M-Score > -2,22 diindikasikan melakukan kemungkinan kecurangan pelaporan keuangan maka diberi skor 1. Perusahaan yang memiliki M-Score < -2,22 diindikasikan tidak melakukan kemungkinan kecurangan pelaporan keuangan maka diberi skor 0 .

$\beta_{1} \quad=$ Koefisien regresi

$\mathrm{IW}_{\mathrm{i}, \mathrm{t}} \quad=$ Total skor indeks kelengkapan

pengungkapan laporan keuangan "i" pada tahun "t"

$=$ Error $($ Kesalahan Penganggu $)$

\section{HASIL PENELITIAN}

\section{Statistik Deskriptif}

Statistik deskriptif merupakan analisis data yang menggambarkan data atau variabel yang akan digunakan dalam suatu penelitian. Pada penelitian ini, deskriptif statistik yang digunakan meliputi, nilai rata-rata (mean), maksimum, minimum dan standar deviasi (Ghozali, 2013).
Deskriptif statistik dalam penelitian ini digunakan untuk menggambarkan seluruh variabel yang digunakan dalam penelitian, yaitu kelengkapan pengungkapan laporan keuangan (disclosure), kemungkinan kecurangan pekaporan keuangan (financial statment fraud), ukuran (size) perusahaan, leverage, likuditas, umur (age) perusahaan, dan status perusahaan.

Tabel 3 Deskriptif Statistik

\begin{tabular}{|c|c|c|c|c|c|}
\hline Variabel & $\mathbf{n}$ & Min. & Max. & Mean & $\begin{array}{c}\text { Std. } \\
\text { Deviasi }\end{array}$ \\
\hline Kelengkapan pengungkapan laporan keuangan & 294 & 0,45 & 0,75 & 0,59 & 0,58 \\
\hline Ukuran (size) Perusahaan & 294 & 22,96 & 33,00 & 28,02 & 1,62 \\
\hline Leverage & 294 & 0,01 & 70,83 & 1,69 & 4,65 \\
\hline Likuiditas & 294 & 0,03 & 27,44 & 3,26 & 14,53 \\
\hline Umur (age) Perusahaan & 294 & 10,00 & 84,00 & 33,35 & 12,64 \\
\hline \multicolumn{6}{|l|}{ Variabel Kategori } \\
\hline \multicolumn{6}{|l|}{ Status Perusahaan } \\
\hline \multicolumn{2}{|l|}{ Keterangan } & Dummy & Frek. & \multicolumn{2}{|c|}{ Persentase } \\
\hline \multicolumn{2}{|l|}{$\begin{array}{l}\text { PMA } \\
\text { PMDN }\end{array}$} & 0 & 152 & \multicolumn{2}{|c|}{$51,7 \%$} \\
\hline \multicolumn{2}{|l|}{ PMDN } & 1 & 142 & \multicolumn{2}{|c|}{$48,3 \%$} \\
\hline \multicolumn{3}{|l|}{ Total } & 306 & \multicolumn{2}{|c|}{$100 \%$} \\
\hline
\end{tabular}

\section{Pengujian Asumsi Klasik}

Berikut ini disajikan hasil asil pengujian asumsi klasik, meliputi uji noemalitas, multikolinearitas, autokorelasi dan heteroskedatisitas sebagai berikut.

Tabel 4 Hasil Uji Normalitas Data

\begin{tabular}{|c|c|c|c|}
\hline $\mathbf{n}$ & Kolmogorov-Smirnov $\mathbf{Z}$ & Asymp. Sig. (2-tailed) & Keterangan \\
\hline 306 & 0,839 & 0,482 & Normal \\
\hline
\end{tabular}

Hasil pengujian pada tabel jumlah observasi Kolmogorov Smirnov dalam penelitian ini sebesar 0,839 . Pengujian menunjukkan bahwa variabel dalam penelitian ini menunjukkan angka signifikan sebesar 0,482 yang berarti variabel dalam penelitian ini terdistribusi normal, karena signifikan lebih dari 0,05 . 
Tabel 5 Hasil Uji Multikolinearitas

\begin{tabular}{|c|c|c|c|}
\hline \multirow{2}{*}{ Variabel } & \multicolumn{2}{|c|}{ Collinearity Statistics } & \multirow{2}{*}{ Keterangan } \\
\cline { 2 - 3 } & Tolerance & VIF & \\
\hline Ukuran (size) Perusahaan & .876 & 1.142 & Bebas Multikolinieritas \\
\hline Leverage & .986 & 1.015 & Bebas Multikolinieritas \\
\hline Likuiditas & .986 & 1.015 & Bebas Multikolinieritas \\
\hline Umur (age) Perusahaan & .884 & 1.131 & Bebas Multikolinieritas \\
\hline Status Perusahaan & .973 & 1.028 & Bebas Multikolinieritas \\
\hline
\end{tabular}

Hasil uji Multikolinearitasmenunjukkan bahwa koefisien untuk kelima variabel independen dengan nilai tolerance variabel ukuran perusahaan 0,876, leverage 0,986, likuiditas 0,986, umur perusahaan 0,884 , dan status perusahaan 0,973 .
Nilai VIF kelima variabel independen dibawah 10, sehingga dapat dinyatakan bahwa model regresi linear berganda penelitian ini bebas dari masalahmultikolinearitas.

Tabel 6 Hasil uji autokorelasi

\begin{tabular}{|c|c|c|c|c|}
\hline $\mathbf{n}$ & $\mathbf{K}$ & $\mathbf{D W}$ & \multicolumn{1}{|c|}{ Kriteria } & \multicolumn{1}{c|}{ Keterangan } \\
\hline 294 & 5 & 1,874 & $1,80942 \leq \mathrm{dw} \leq 2,19058$ & Tidak terjadi autokorelasi, \\
\hline
\end{tabular}

Hasil pengujian autokorelasi data dengan transformasi data ke bentuk Lagseperti yang ditunjukkan pada tableyang menunjukkan angka sebesar 1,834 berarti variabel dalam penelitian ini tidak terkena autokorelasi. Maka dari hasil tersebut pengujian hipotesis dengan menggunakan regresi linier berganda dalam penelitian ini dapat dilakukan.

Tabel 7 Hasil Uji Heteroskedastisitas

\begin{tabular}{|l|l|l|l|}
\hline \multicolumn{1}{|c|}{ Variabel } & \multicolumn{1}{c|}{ t } & Sig. & \multicolumn{1}{c|}{ Keterangan } \\
\hline (Constant) & 4,064 & 0,000 & - \\
\hline SIZE & $-1,628$ & 0,105 & Bebas heteroskedastisitas \\
\hline LEVERAGE & 0,801 & 0,424 & Bebas heteroskedastisitas \\
\hline LIKUIDITAS & $-2,252$ & 0,801 & Bebas heteroskedastisitas \\
\hline AGE & $-0,836$ & 0,404 & Bebas heteroskedastisitas \\
\hline STATUS & $-0,370$ & 0,712 & Bebas heteroskedastisitas \\
\hline
\end{tabular}

Berdasarkan tabel di atas dapat dilihat hasil regresi nilai absolut residual terhadap variabel independen pada model regresi. Pada tabel tersebut dapat dilihat bahwa pada model regresi variabel independen dari seluruh persamaan signifikansi >

$0,05(5 \%)$. Jadi dapat disimpulkan model regresi pertama bebas dari masalah heteroskedastisitas.

Tabel 8 Uji Normalitas Regresi LogistikOne-Sample Kolmogorov-Smirnov Test

\begin{tabular}{|l|c|c|}
\hline & Unstandarsized Residual & Keterangan \\
\hline Kolmogorov-Smirnov Z & 5,517 & \\
\hline Asymp. Sig. (2-tailed) & 0,000 & Tidak Normal \\
\hline
\end{tabular}

Hasil uji one-sample kolmogorov smirnov menunjukkan hasil bahwa nilai dari kolmogorovsmirnov $Z$ sebesar 5,517 dengan asymp. sig (2tailed) $0,000<0,005$ yang berarti nilai residual tidak terdistribusi secara normal. Asumsi Central Limit Theorem menyatakan bahwa untuk sampel

Berikut hasil pengujian hipotesis untuk model 1 dan model 2 disajikan pada tabel 9 dan 10 berikut ini. yang besar terutama lebih dari $30(n \geq 30)$ distribusi sampel tetap dianggap mendekati distribusi normal (Dielman, 1961 dalam Ghozali, 2013).

\section{Pengujian Hipotesis}


Tabel 9 Hasil Uji Model I (Hipotesis 1,2,3,4 dan 5)

\begin{tabular}{|c|c|c|c|c|}
\hline \multicolumn{5}{|c|}{ Uji Statistik t } \\
\hline Variabel & $\mathbf{T}$ & Sig. & Kriteria & Hipotesis \\
\hline SIZE & 8,293 & 0,000 & Sig. $\leq 0,05$ dan pengaruh $(+)$ & H1 didukung \\
\hline LEVERAGE & 1,342 & 0,180 & Sig. $\geq 0,05$ dan pengaruh $(+)$ & H2 ditolak \\
\hline LIKUIDITAS & $-0,177$ & 0,860 & Sig. $\geq 0,05$ dan pengaruh (-) & H3 ditolak \\
\hline AGE & 0,579 & 0,563 & Sig. $\geq 0,05$ dan pengaruh $(+)$ & H4 ditolak \\
\hline STATUS & 4,189 & 0,000 & Sig. $\leq 0,05$ dan pengaruh $(+)$ & H5 didukung \\
\hline \multicolumn{5}{|c|}{ Uji Statistik F } \\
\hline \multirow{2}{*}{\multicolumn{3}{|c|}{$\frac{\mathbf{F}}{23,196}$}} & \multirow{2}{*}{\multicolumn{2}{|c|}{$\begin{array}{c}\text { Sig. } \\
0,000\end{array}$}} \\
\hline & & & & \\
\hline \multicolumn{5}{|c|}{ Koefisien Determinasi $\mathbf{R}^{2}$} \\
\hline \multicolumn{3}{|c|}{ R Square } & \multicolumn{2}{|c|}{ Adjusted R Square } \\
\hline \multicolumn{3}{|c|}{0,288} & \multicolumn{2}{|c|}{0,275} \\
\hline
\end{tabular}

Hasil Pengujian hipotesis menunjukkan bahwa Ukuran (size) Perusahaan berpengaruh signifikan terhadap kelengkapan pengungkapan laporan keuangan. Hasil ini sejalan dengan Wallace dkk, Devi dan Suardana (2014), dan Benardi dkk (2009).Perusahaan besar lebih diawasi atau disorot secara ketat oleh pemerintah, serta badan legulator yang lain. Sehingga pengungkapan-pengungkapan yang lebih luas akan mengurangi tekanan dari pemerintah maupun regulator. Selain itu Perusahaan besar lebih membutuhkan banyak modal, sehingga pengungkapan yang lebih luas akan lebih menarik investor guna meningkatkan likuiditas serta memudahkan pembiayaan. Perusahaan besar juga memegang agency cost yang lebih besar karena pemegang sahamnya tersebar. Oleh karena itu pengungkapan yang luas akan mengurangi agency cost. Selanjutntanya variabel Leverage tidak berpengaruh signifikan terhadap kelengkapan pengungkapan laporan keuangan. Hasil ini tidak sejalan dengan Mahmud dan Irianto (2009) dan Almilia dan Retrinasari (2007).Hal ini mungkin disebabkan perusahaan yang memiliki tingkat leverage yang tinggi akan membuat keadaan keuangan perusahaan menjadi buruk, hal ini disebabkan semakin besarnya pendanaan perusahaan yang berasal dari hutang, sehingga semakin tinggi pula resiko yang akan ditanggung oleh perusahaan. Manajemen akan berusaha seminimal mungkin untuk menunjukkan laporan keuangannya untuk menghindari tekanan dari para debitur. Dan para debitur dapat menekan pihak manajemen untuk mendahulukan kepentingan mereka dari pada aktivitas perusahaan.Likuiditas tidak berpengaruh signifikan terhadap kelengkapan pengungkapan laporan keuangan dan menunjukkan arah negatif. Hasil penelitian ini tidak sejalan dengan Winarto (2012) dan Christanty (2004), yang menemukan hasil sebaliknya. Tingginya kinerja keuangan merupakan suatu keharusan karena kondisi keuangan yang likuid akan memudahkan perusahaan menjalankan operasionalnya sehari-sehari. Hal ini dapat diartikan bahwa perusahaan yang memiliki likuiditas yang tinggi akan mencerminkan perusahaan tersebut juga memiliki modal kerja tersedia yang cukup sehingga perusahaan akan cenderung mengungkapkan informasi seperlunya saja. Sebaliknya, perusahaan yang memiliki likuiditas rendah akan menyebabkan manajemen ingin menyampaikan informasi lain yang lebih banyak untuk menutupi likuiditasnya yang rendah tersebut, dimana semua tindakan manajemen perusahaan tersebut adalah dalam rangka untuk menjaga kelangsungan usaha perusahaan melalui pengungkapan laporan keuangan sebagai alat pengawasan bagi kinerja manajemen.Umur perusahaan tidak berpengaruh signifikan terhadap kelengpan pengungkapan laporan keuangan. Hasil ini tidak mendukung penelitian Irawan (2006) dan Winarto (2012).Semakin lama perusahaan berdiri, maka akan membutuhkan banyak biaya yang harus dikeluarkan untuk mengungkapkan informasi tersebut, sehingga perusahaan berusaha menekan dari biaya-biaya yang harus dikeluarkan untuk keperluan pengungkapan informasi tersebut. Jadi perusahaan yang sudah lama berdiri akan mengungkapkan informasi yang menurut mereka akan banyak disorot oleh investor dan dengan harapan para investor akan tertarik membeli saham perusahaan. Berikutnya status perusahaan berpengaruh signifikan terhadap kelengkapan pengungkapan laporan keuangan. Hasil ini sejalan dengan Irawan (2006) yang membuktikan status perusahaan berpengaruh signifikan terhadap kelengkapan pengungkapan laporan keuangan. Perusahaan dengan modal asing lebih menginginkan manajer untuk mengungkapkan informasi secara lebih luas. Hal ini dikarenakan kendala jarak yang relatif jauh antara perusahaan dengan pemodal asing sehingga tidak bisa melihat langsung kondisi perusahaannya dan hanya dapat melihat kondisi perusahaan melalui laporan keuangannya. Sementara itu dari pihak manajer juga ingin meyakinkan pihak investor asing bahwa perusahaan dalam kondisi baik. 
Tabel 10 Hasil Uji Model II (Hipotesis 6)

\begin{tabular}{|c|c|c|c|}
\hline \multicolumn{4}{|c|}{ Uji t } \\
\hline & Variabel & Koef. & Sig. \\
\hline Kelen & an pengungkapan laporan keuangan & 2,435 & 0,232 \\
\hline \multicolumn{4}{|c|}{ Uji Kelayakan Model (Hosmer and Lemeshow Test) } \\
\hline & Chi-square & Df & Sig. \\
\hline & 7,060 & 8 & 0,530 \\
\hline \multicolumn{4}{|c|}{ Koefisien determinasi $\mathbf{R}^{2}$} \\
\hline Step & -2 Log likelihood & Cox \& Snell R Square & Nagelkerke R Square \\
\hline 1 & $403.062^{\mathrm{a}}$ & 0,005 & 0,007 \\
\hline
\end{tabular}

Hasil Pengujian Hipotesis 6, menunjukkan bahwa kelengkapan pengungkapan laporan keuangan tidak berpengaruh signifikan terhadap kemungkinan kecurangan pelaporan keuangan. Hasil ini mengindikasikan bahwa tidak ada kaitan antara pengungkapan laporan keuangan dan kemungkinan kecurangan pelaporan keuangan.Hasil ini tidak sejalan dengan Rezaee (2005) bahwa kecurangan pelaporan keungan berkaitan berkaitan dengan pengungkapan secara memadai standar, prinsip, praktek akuntansi dan informasi keuangan yang berkaitan. Selain itu data deskriptif tingkat kelengkapan pengungkapan laporan keuangan ratarata hanya sebesar $59,9 \%$, hal ini termasuk rendah, yang mengindikasikan belum optimalnya tingkat kelengkapan pengungkapan laporan keuangan pada perusahaan manufaktur di Indonesia.

\section{KESIMPULAN}

Penelitian ini bertujuan untuk menguji dan memperoleh bukti empiris mengenai pengaruh karakteristik perusahaanyang terdiri dari ukuran perusahaan, leverage, likuiditas, umur perusahaann dan status perusahaan terhadap kelengkapan pengungkapan laporan keuangan dan konsekuensinya terhadap kemungkinan kecurangan pelaporan keuangan pada perusahaan manufaktur yang terdaftar diBursa Efek Indonesia. Berdasarkan hasil penelitian dapat disimpulan bahwa. Ukuran (size) Perusahaan berpengaruh signifikan terhadap kelengkapan pengungkapan laporan keuangan. Leverage tidak berpengaruh signifikan terhadap kelengkapan pengungkapan laporan keuangan. Likuiditas tidak berpengaruh signifikan terhadap kelengkapan pengungkapan laporan keuangan dan menunjukkan arah negatif. Umur perusahaan tidak berpengaruh signifikan terhadap kelengpan pengungkapan laporan keuangan. Status perusahaan berpengaruh signifikan terhadap kelengkapan pengungkapan laporan keuangan. Kelengkapan pengungkapan laporan keuangan tidak berpengaruh signifikan terhadap kemungkinan kecurangan pelaporan keuangan.

\section{DAFTAR PUSTAKA}

Adhi, N. 2012. "Pengaruh Karakteristik Perusahaan Terhadap Luas Pengungkapan Sukarela Dan Implikasinya Terhadap Asimetri Informasi”. Jurnal Ekonomika Dan Bisnis. Diponegoro

AICPA. 2002. Consideration of Fraud in a Financial Statement Audit. Statement on Accounting Standards (SAS) No. 99

Almilia, Luciana Spica dan Ikka Retrinasari. 2003.

"Analisis Pengaruh Karakteristik

Perusahaan terhadap Kelengkapan

Pengungkapan dalam Laporan Tahunan

Perusahaan yang terdaftar di BEJ". Jurnal Akuntansi dan Bisnis. Vol.5, No.2, Agustus 2003: 61-70

Andriyanti, Elyana Noor. 2007. Pengaruh Struktur

Aktiva, Ukuran Perusahaan, dan Operating Leverage terhadap Struktur Modal Pada Perusahaan Makanan dan Minuman Yang terdaftar Di Bursa Efek Jakarta (BEJ). Skripsi S1, Universitas Negeri Semarang, Semarang.

Agustina, Dewi. 2006. “Analisi Beberapa Faktor yang Mempengaruhi Kelengkapan Pengungkapan Laporan Keuangan Perusahaan Jasa Transportasi, Perdagangan dan Manufaktur yang Tercatat di Bursa Efek Jakarta”. Jurnal Bisnis dan Akuntansi, Vol. 8, No 3, hal. 219-246

Badan pengawas Pasar Modal dan Lembaga Keuangan. 2006. Annual Report Bapepam-LK Tahun 2006. Jakarta

Badan pengawas Pasar Modal dan Lembaga Keuangan. 2011. Annual Report Bapepam-LK Tahun 2011. Jakarta

Benardi, Meliana K, Sutrisno, dan prihat Assih. 2009. "Faktor-faktor Yang Mempengaruhi Luas Pengungkapan dan Implikasinya terhadap Asimetri Informasi (Studi Pada Perusahaan Perusahaan Sektor Manufaktur Yang Go 
public di BEI)". Simposium Nasional Akuntansi XII. Palembang.

Beneish. M.D. 1999. The Detection of Earning Manipulation, Financial Analyst Journal.

Daljono, M. 2013. "Pendetekisan kecurangan laporan keuangan melalui faktor risiko tekanan dan peluang". Diponegoro journal of accounting 2(2): 1-12.

Daniel, N. U. 2013. Pengaruh ukuran perusahaan, leverage dan likuiditas terhadap luas pengungkapan laporan keuangan. 1-24.

Deegan, C. 2002. "The legitimising effect of social and environmental disclosures $A$ theoretical foundation, Accounting”. Auditing and Accountability Journal, 15(3), pp. 282-311.

Ghozali, Imam. 2013. Aplikasi Analisis Multivariate dengan program SPSS Edisi: 7. Semarang : Badan penerbit UNDIP.

Hadiningsih, Murni. 2007. “Analisis Dampak Jangka Panjang Merger dan Akuisisi terhadap Kinerja Keuangan Perusahaan Pengakuisisi dan Perusahaan Diakuisisi di Bursa Efek Jakarta (BEJ)”. Jurnal, Jurusan Manajemen Keuangan, Fakultas Ekonomi, Universitas Islam Indonesia, Yogyakarta.

Husaini. 2009. Komite Audit dan Audit Internal: Integritas Pengawasan Korporasi. Unpad Press. Bandung.

Irawan, Bambang, 2006. Faktor-Faktor yang Mempengaruhi Kelengkapan Pengungkapan Laporan Keuangan pada Perusahaan manufaktur yang Terdaftar di Bursa Efek Jakarta.Skripsi. Fakultas Ekonomi, Universitas Islam Indonesia, Yogyakarta.

IAI. 2013. Pernyataan Standar Akuntansi Keuangan (PSAK) 1 (Revisi 2013) Instrumen Keuangan: Penyajian Laporan Keuangan. Jakarta: Ikatan Akuntan Indonesia.

Irianto, M. M. d. G. 2009. Faktor-faktor fundamental yang mempengaruhi kelengkapan pengungkapan laporan keuangan. 1-25.

Jensen, Michael C \& Meckling, William H. 1976. "Theory of The Firm: Managerial Behavior, Agency Costs and Ownership Structure". Journal of Financial Economics, Volume 3

Kartika, Andi. 2007. "Faktor-faktor yang mempengaruhi kelengkapan pengungkapan laporan keuangan pada perusahaan manufaktur yang terdaftar di bursa efek indonesia". Jurnal Bisnis dan
Ekonomi (JEB). Fakultas Ekonomi Unisbank Semarang

Lev B., and S.R. Thiagarajan, 1993. Fundamental Information Analysis, Journal of Accounting Research 31: 190-215.

Miswanto dan Suad Husnan. 1999. The Effect of Operating Leverage, cyclicality, and firm size on Business Risk".Gadjah Mada International Journal of Business. Vol 1 No.1 (Mei): 29-43.

Nabila, A. R. 2013. Deteksi Kecurangan Laporan Keuangan Dalam Perspektif Fraud Triangle. Diponegoro: 1-72.

Norbarani, Listianan. 2012. Pendeteksiian Kecurangan Laporan Keuangan dengan Analisis Fraud Triangle yang Diadopsi dalam SAS no. 99.

Purwandari, Arum dan Agus Purwanto. 2012. "Pengaruh Profitabilitas, Leverage, Struktur Kepemilikan Dan Status Perusahaan terhadap Pengungkapan Laporan Keuangan Pada Perusahaan Manufaktur Di Indonesia". Jurnal Akuntansi. Vol. 1, No. 2, Hal 1-10

Rahajeng, Rahmi Galuh. 2010. "Faktor-faktor Yang Mempengaruhi Pengungkapan Sosial (Social Disclosure) Dalam Laporan Tahunan Perusahaan. Jurnal Akuntansi. Universitas Diponegoro. Semarang

Rezaee, Zabihollah 2005, Cause, Consequences, and Deterence Of Financial Statement Fraud. Critical Perspective in Accounting, 16, 277-298.

Salman, Kautsar R. 2007. Penggunaan Rasio Keuangan Untuk Mengidentifikasi Kecurangan Pelaporan Keuangan. http:/kautsartax.wordpress.com/ penggunaan rasio keuangan untuk mengidentifikasi kecurangan pelaporan keuangan/. Diakses 2 Oktober 2014

Simanjuntak, Binsar H dan Widiastuti. 2004. "Faktor-faktor yang Mempengaruhi Kelengkapan Pengungkapan Laporan Keuangan pada Perusahaan Manufaktur yang terdaftar di BEJ". Jurnal Riset Akuntansi Indonesia 7. (3).

Suripto, Bambang. 1999. "Pengaruh Karakteristik Perusahaan Terhadap Luas Pengungkapan Sukarela dalam Laporan Tahunan”. Simposium Nasional Akuntansi II. Malang.

Suardana, I. 2014. "Pengaruh ukuran perusahaan, likuiditas, leverage dan status perusahaan pada kelengkapan pengungkapan laporan keuangan". Ejurnal Akuntansi Universitas Udayana8: 474-492.

Tristanti, Leony Lovancy. 2012. “Analisis Pengaruh Karakteristik Perusahaan 
Terhadap Kelengkapan Pengungkapan Sukarela”. Jurnal. Universitas Diponegoro. Semarang

Wicaksono, Bagus Bintang, 2011, Pengaruh Karakteristik Perusahaan Terhadap Luas Pengungkapan Sukarela Pada Laporan Keuangan. Universitas Diponegoro, Semarang.

winarto, M. j. 2012. Analisis Pengaruh Rasio Keuangan, Pertumbuhan, Ukuran Perusahaan Dan Umur Perusahaan Terhadap Kelengkapan Pengungkapan Laporan Keuangan Pada Perusahaan Pertambangan Batu Bara Di Indonesia. 1-8. 